OnLine Journal of Biological Sciences 11 (2): 63-69, 2011

ISSN 1608-4217

(C) 2011 Jodłowska and Latała, This open access article is distributed under a Creative Commons Attribution

(CC-BY) 3.0 license

\title{
The Comparison of Spectrophotometric Method and High-Performance Liquid Chromatography in Photosynthetic Pigments Analysis
}

\author{
Sabina Jodłowska and Adam Latała \\ Institute of Oceanography, Łaboratory of Marine Plańt Ecophysiology, \\ University of Gdańsk, Av. Piłsudskiego 46, PL-81378 Gdynia, Poland
}

\begin{abstract}
Problem statement: Spectrophotometric method and High-Performance Liquid Chromatography (HPLC) are the most useful tools to photosynthetic pigments analysis. The main objective of this reaserch was to compere the results obtained by these two independent methods in experiments under controlled laboratory conditions. Approach: Comparison between spectrophotometric and HPLC methods for pigment analysis was carried out on Baltic cyanobacterium Geitlerinema amphibium, which is distinguished by photoacclimation capacity and wide range of changes in pigment cell concentration depending on light and temperature conditions. Results: The degree of relationship between the methods of pigment measurement was described by correlation coefficients, which were $0.970,0.978$ and 0.997 for the results of chlorophyll a, carotenoids and carotenoids to chlorophyll a ratio, respectively. Conclusion: It was found that spectrophotometric method gave comparable results to HPLC method, especially when there were not degradation products of chlorophyll a in samples. In contrast with HPLC method it allows to determine the only total amount of carotenoid pigments. Estimation of the carotenoids to chlorophyll a ratio is useful to understand the reaction of organism to changing environmental light condition.
\end{abstract}

Key words: Photosynthetic pigment analysis, currently reverse-phase high-performance, cyanobacterium Geitlerinema amphibium, ambient temperature, mixed populations, Culture Collection of Baltic Algae (CCBA)

\section{INTRODUCTION}

The determination of chlorophyll and carotenoid pigments is universally applied in oceanography and limnology. Photosynthetic pigment analysis is useful method to estimate phytoplankton biomass and productivity. Measurement of chlorophyll concentration helps us to record the variability of phytoplankton development over time and to assess its role and position in aquatic environment. Chlorophyll a is often used as the standard basis on which to calculate photosynthetic and respiratory rate (Ritchie, 2006). Carotenoid concentrations are often used to describe the composition of phytoplankton in water and to estimate their abundance in mixed populations (Wright et al., 1991; Millie et al., 1993; Andersen et al., 1996; Stoń and Kosakowska, 2002; Buchaca et al., 2005; Llewellyn et al., 2005; Wulff et al., 2005; Schagerl and Kunzl, 2007). However, estimation of the ratio of carotenoids to chlorophyll a is useful to understand the reaction of organism to changing environmental light condition (Jodłowska and Latała, 2010).
The standard analytical methods for chlorophylls are based on spectrophotometry or fluorometry (Strickland and Parsons, 1972). The methods are very simple and useful for quick estimation the amount of pigments, but do not always cope well with the complex range of pigments and pigment degradation products found in natural samples. The absorption spectrums of chlorophyll b and $\mathrm{c}$ overlap with chlorophyll a spectrum. Moreover, degradation products of chlorophyll a (chlorophyllides, allomers, pheopigments) have the same maximum absorption at the value $665 \mathrm{~nm}$ (Meyns et al., 1994). In addition spectrophotometric method enables to estimate the only total and approximate amount of carotenoids, but not the amounts of individual carotenoids (Mantoura and Llewellyn, 1983). Currently reverse-phase High-Stoń Performance Liquid Chromatography (HPLC) is usually applied method for photosynthetic pigments determination. Despite the method requires having expensive and sophisticated apparatus, it allows us to separate all the compounds from the mixture (RiauxGobin et al., 1987; Millie et al., 1993). 
At present work photosynthetic pigments were determined by two methods: spectrophotometric and chromatographic with the aim of comparing the results obtained by two independent methods. Chlorophyll a and carotenoid pigments were analyzed in cyanobacterium G. amphibium, which shows acclimation capacity to irradiance and a wide range of changes in photosynthetic pigment concentration (Latała and Misiewicz, 2000).

\section{MATERIALS AND METHODS}

The experiments were carried out on cyanobacterium Geitlerinema amphibium BA-13 (AG. ex GOM.) Anagnostidis and Komarek (1989). This strain was isolated from microbial mats of the costal part of Puck Bay near Władyslawowo (Southern Baltic, Poland) (Latała and Misiewicz, 2000) and is maintained as unialgal culture in Culture Collection of Baltic Algae

(CCBA) (http://pasat.ocean.univ.gda.pl/ ccba/) at the Institute of Oceanography, University of Gdańsk, Poland (Latała et al., 2006). The batch cultures were carried out in sterilized BG-11 medium (Stanier et al., 1971) in $300 \mathrm{~mL}$ glass Erlenmeyer flasks. The media were prepared from natural Baltic water with salinity of about 8 psu after filtering through GF/C Whatman filters. Microscopic observations of cyanobacteria cultures did not show bacterial contaminations.

Appling factorial experiments the following combinations of light and temperature were used:

Light: The incubation vessels were kept in incubators in 16:8 h L:D cycle and irradiances: 5, 65 and $125 \mu \mathrm{mol}$ photons $\cdot \mathrm{m}^{-2} \cdot \mathrm{sec}^{-1}$. The source of Photosynthetic Active Radiation (PAR) were fluorescent lamps, Sylvania cool white $40 \mathrm{~W}$ and for more intensive light-combined with halogen lamps, Sylvania $100 \mathrm{~W}$. The intensity of PAR was measured using a quantum-meter Li Cor (LI-189) with a cosine collector.

Temperature: The influence of temperature was tested in following values: $15,22.5$ and $30^{\circ} \mathrm{C}$.

The extraction of chlorophyll a and carotenoids was carried out in cold $90 \%$ acetone, in darkness, at $20^{\circ} \mathrm{C}$ for $4 \mathrm{~h}$ (Strickland and Parsons, 1972). To improve extraction, the cells were disintegrated for 2 min in an ultrasonic bath. To remove cell debris and filter particles the pigment extract was centrifuged at $5000 \mathrm{rpm}$ for 5-10 min.

The extinction was estimated at 664,480 and 750 nm with spectrophotometer UV-VIS 1202 Shimadzu and using $1 \mathrm{~cm}$ glass cuvette. The concentration of carotenoids was calculated by the formula (Strickland and Parsons, 1972): Car $\left(\mu \mathrm{g} \cdot \mathrm{mL}^{-1}\right)=4 \cdot\left(\mathrm{E}_{480^{-}}\right.$ $\left.\mathrm{E}_{750}\right) \cdot \mathrm{V}_{\mathrm{a}} \cdot \mathrm{V}_{\mathrm{b}}{ }^{-1}$ while the concentration of chlorophyll a was estimated by the formula: Chla $\left(\mu \mathrm{g} \cdot \mathrm{mL}^{-1}\right)=$ 11.403 $\cdot\left(\mathrm{A}_{664}-\mathrm{A}_{750}\right) \cdot \mathrm{V}_{\mathrm{a}} \cdot \mathrm{V}_{\mathrm{b}}{ }^{-1}$, derived on the basis of a factor. Designations at the formulas are: $\mathrm{V}_{\mathrm{a}}$-extract volume $(\mathrm{mL})$ and $\mathrm{V}_{\mathrm{b}}$-sample volume $(\mathrm{mL})$.

To analyze pigment composition a Waters liquid chromatography equipped with diode array detector was used. The absorption spectrum for each of the separated pigments was measured from $350-700 \mathrm{~nm}$, but detection at $440 \mathrm{~nm}$. The separation was carried out at ambient temperature, on Vydac 201TP (C18) analytical column (dimensions $250 \times 4.6 \mathrm{~mm}$ ) protected by a guard column. Pigments were analysed using the method of (Mantoura and Llewellyn, 1983), which was modified and adjusted to experimental material (Jodłowska and Latała, 2003).

To identification and quantification of pigments, high purity standards (myxoxanthophyll, zeaxanthine, $\beta$-carotene and chlorophyll a) were used from International Agency for ${ }^{14} \mathrm{C}$ Determination VKI in Denmark. To determination of cis- $\beta$ carotene, standard culture of Dunaliella tertiolectaCCMP (Wright et al., 1991) was used.

The experiments were carried out in double and from each replicate two independent samples were analyzed. To determine the influence of light and temperature and their interaction on pigment concentration in $G$. amphibium cultures, factorial experiments were carried out. In the method applied the values of the independent variables occur at the same intervals and always in quadruplicate. It enables calculations by creating polynomials that are mutually orthogonal. The fitting of the polynomial by the method ' ${ }^{\prime}$ (ksi prim) is simplified by the use of tables of orthogonal polynomials (Fisher and Yates, 1963). The method makes it possible to determine the influence of the investigated factors and their interactions on pigment concentration by calculation of regression equations. The equations served to construct surface plots with the use of Surfer Program (v.8.01). Two-way analysis of variance was used to assess the main effects and their interaction.

\section{RESULTS}

Chromatographic analyses of pigment cell content in G. amphibium showed the presence of chlorophyll a 
and the following carotenoids: myxoxantophyll, zeaxanthine, $\beta$-carotene and cis- $\beta$-carotene Table 1 . The results of pigment concentration obtained by chromatographic and spectrophotometric method Table 2 were used to plot the correlation curves describing linear relationship between applied methods of pigment detection (Fig. 1). The degree of relationship was described by correlation coefficients. In case of chlorophyll a results the correlation coefficient was 0.970 (Fig. 1A) whereas for carotenoids it was 0.978 (Fig. 1B). The highest correlation coefficient was noted for the results of the ratio of carotenoids to chlorophyll a and it was 0.997 (Fig. 1C).

The factorial experiments showed that the ratio of carotenoids to chlorophyll a was influenced by PAR as well as temperature, but stronger effect was noted in the case of irradiance. It was reflected in variance analysis Table 3 . On chromatographic method Table 3A, $96 \%$ of total sum of squares was accounted for by irradiation sum of squares whereas for temperature and interaction of the main factors it was only: 3.3 and $0.7 \%$. The results of variance analysis obtained spectrophotometrically are similar Table 3B. About $93 \%$ of total sum of squares was accounted for by irradiation sum of squares whereas for temperature and interaction of the main factors it was only about: 5 and $2 \%$. It was noted that the values of the ratio of carotenoids to chlorophyll a varied in direct proportion to irradiance and inverse proportion to temperature. On the basis of factorial experiments it was found that the highest values of measured parameter was in the range of irradiance of 100-120 $\mu \mathrm{mol}$ photons $\cdot \mathrm{m}^{-2} \cdot \mathrm{s}^{-1}$ and temperature of $15-20^{\circ} \mathrm{C}$ (Fig. 2).

Table 1: Spectral properties of chlorophyll and carotenoid pigments of G. amphibium

\begin{tabular}{llll}
\hline $\begin{array}{l}\text { Peak } \\
\text { number }\end{array}$ & Pigment & $\begin{array}{l}\text { Retention } \\
\text { time }(\mathrm{min})\end{array}$ & $\begin{array}{l}\text { Absorption } \\
\text { maxima }(\mathrm{nm})\end{array}$ \\
\hline 1 & Myxoxanthophyll & 10.46 & 475.0504 .1 \\
2 & Zeaxanthine & 12.83 & 453.3478 .7 \\
3 & Chlorophyll a & 15.02 & 431.5665 .0 \\
4 & $\beta$-carotene & 26.61 & 453.3478 .7 \\
5 & Cis- $\beta$-carotene & 27.51 & 446.0471 .4 \\
\hline
\end{tabular}

Table 2: Mean values (standard deviation) of chlorophyll a and carotenoids

\begin{tabular}{lllll}
\hline \multirow{2}{*}{$\begin{array}{l}\text { Irradiance } \\
\left(\mu \mathrm{mol} \mathrm{photons} \cdot \mathrm{m}^{-2} \cdot \mathrm{sec}^{-1}\right)\end{array}$} & Method & 15 & 22.5 & 30 \\
\hline 5 & Spectrophotometer & $0.27(0.040)$ & $0.49(0.024)$ & $0.52(0.038)$ \\
& HPLC & $0.29(0.085)$ & $0.51(0.055)$ & $0.65(0.096)$ \\
65 & Spectrophotometer & $0.02(0.003)$ & $0.43(0.028)$ & $0.32(0.021)$ \\
& HPLC & $0.02(0.003)$ & $0.50(0.022)$ & $0.37(0.011)$ \\
& Spectrophotometer & $0.03(0.002)$ & $0.38(0.023)$ & $0.47(0.037)$ \\
& HPLC & $0.03(0.004)$ & $0.49(0.069)$ & $0.55(0.027)$ \\
\hline
\end{tabular}

Table 1B: Mean values (standard deviation) of chlorophyll a Concentration $\left(\mu \mathrm{g} \cdot \mathrm{mL}^{-1}\right)$ and the ratio of carotenoids to chlorophyll a

\begin{tabular}{|c|c|c|c|c|}
\hline \multirow[b]{2}{*}{$\begin{array}{l}\text { Irradiance } \\
\left(\mu \mathrm{mol} \text { photons } \cdot \mathrm{m}^{-2} \cdot \mathrm{sec}^{-1}\right)\end{array}$} & \multirow[b]{2}{*}{ Method } & \multicolumn{3}{|c|}{ Temperature $\left({ }^{\circ} \mathrm{C}\right)$} \\
\hline & & 15 & 22.5 & 30 \\
\hline \multirow[t]{2}{*}{5} & Spectrophotometer & $0.09(0.001)$ & $0.18(0.007)$ & $0.17(0.007)$ \\
\hline & HPLC & $0.10(0.030)$ & $0.17(0.048)$ & $0.18(0.030)$ \\
\hline \multirow[t]{2}{*}{65} & Spectrophotometer & $0.02(0.009)$ & $0.33(0.006)$ & $0.24(0.016)$ \\
\hline & HPLC & $0.02(0.001)$ & $0.40(0.055)$ & $0.30(0.010)$ \\
\hline \multirow[t]{2}{*}{125} & Spectrophotometer & $0.04(0.001)$ & $0.50(0.019)$ & $0.58(0.014)$ \\
\hline & HPLC & $0.05(0.002)$ & $0.64(0.051)$ & $0.68(0.056)$ \\
\hline
\end{tabular}

Table 1C: Mean values (standard deviation) of chlorophyll a G. amphibium growing at different temperature and irradiance conditions on the basis of spectrophotometric and HPLC method

\begin{tabular}{|c|c|c|c|c|}
\hline \multirow{2}{*}{$\begin{array}{l}\text { Irradiance } \\
\left(\mu \mathrm{mol} \text { photons } \cdot \mathrm{m}^{-2} \cdot \mathrm{sec}^{-1}\right)\end{array}$} & \multirow[b]{2}{*}{ Method } & \multicolumn{3}{|c|}{ Temperature $\left({ }^{\circ} \mathrm{C}\right)$} \\
\hline & & 15 & 22.5 & 30 \\
\hline \multirow[t]{2}{*}{5} & Spectrophotometer & $0.37(0.006)$ & $0.36(0.015)$ & $0.34(0.004)$ \\
\hline & HPLC & $0.36(0.004)$ & $0.32(0.003)$ & $0.29(0.008)$ \\
\hline \multirow[t]{2}{*}{65} & Spectrophotometer & $1.14(0.063)$ & $0.76(0.016)$ & $0.75(0.044)$ \\
\hline & HPLC & $1.00(0.091)$ & $0.80(0.096)$ & $0.79(0.098)$ \\
\hline \multirow[t]{2}{*}{125} & Spectrophotometer & $1.44(0.029)$ & $1.29(0.053)$ & $1.24(0.058)$ \\
\hline & HPLC & $1.44(0.061)$ & $1.30(0.029)$ & $1.24(0.092)$ \\
\hline
\end{tabular}


OnLine J. Biol. Sci., 11 (2): 63-69, 2011

Table 3: Two-way factorial variance analysis of the ratio of carotenoids to chlorophyll $a$ in $G$. amphibium on the basis of HPLC

\begin{tabular}{lcllr}
\hline & DF & Ss & Mss & \multicolumn{1}{l}{ F } \\
\hline Source of variation & 2 & 5.87 & 2.94 & $619.23^{*}$ \\
Irradiation & 2 & 0.20 & 0.10 & $21.33^{*}$ \\
Temperature & 4 & 0.04 & 0.01 & $1.98^{*}$ \\
Interaction & 27 & & 0.00 & \\
Error & & 6.11 & & \\
\hline
\end{tabular}

Table 1B: Two-way factorial variance analysis of the ratio of carotenoids to chlorophyll $a$ in $G$. amphibium on the basis of spectrophotometric method

\begin{tabular}{lcccr}
\hline & DF & Ss & Mss & \multicolumn{1}{c}{ F } \\
\hline Source of variation & 2 & 5.52 & 2.76 & $15425.79^{*}$ \\
Irradiation & 2 & 0.30 & 0.15 & $835.33^{*}$ \\
Temperature & 4 & 0.11 & 0.03 & $147.35^{*}$ \\
Interaction & 27 & & 0.00 & \\
Error & & 5.93 & & \\
\hline
\end{tabular}

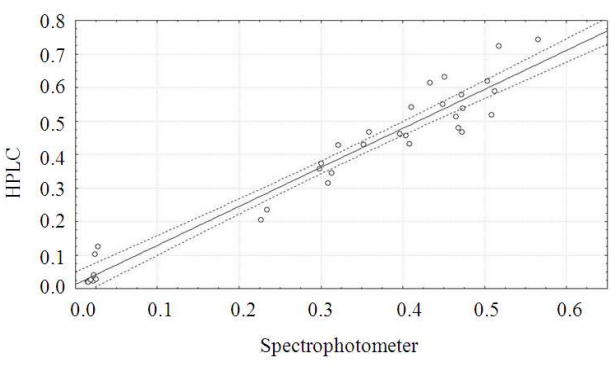

(a)

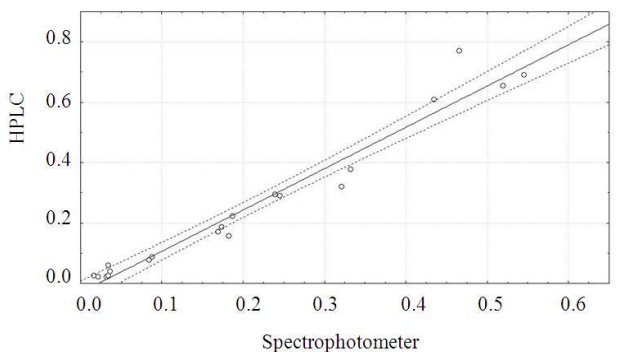

(b)

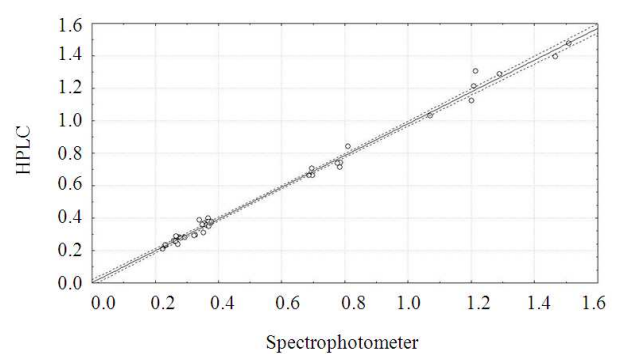

(c)

Fig. 1: Correlation coefficients between the results obtained by spectrophotometric and HPLC method (A) chlorophyll a $\left(\mu \mathrm{g} \cdot \mathrm{mL}^{-1}\right)$, (B) carotenoids $\left(\mu \mathrm{g} \cdot \mathrm{mL}^{-1}\right),(\mathrm{C}) \mathrm{car} / \mathrm{chla}$

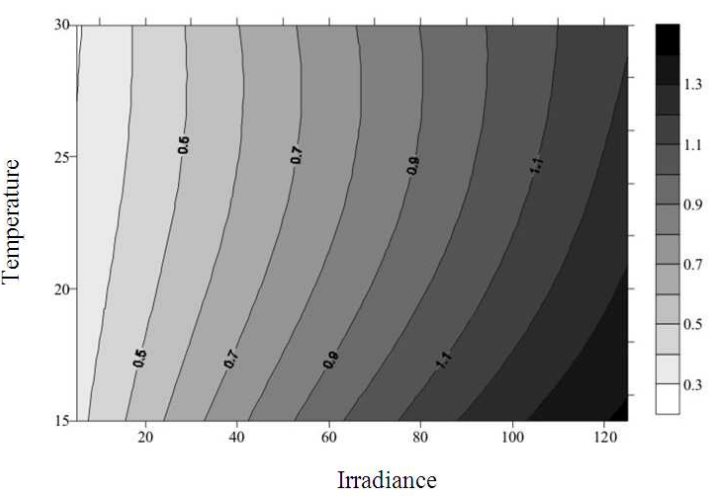

(a)

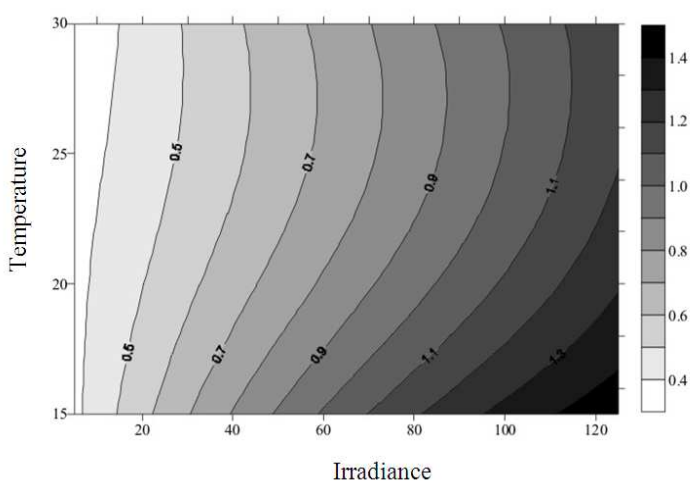

(b)

Fig. 2: Response-surface estimation of carotenoids/chlorophyll a ratio in $G$. amphibium at different irradiance $(\mu \mathrm{mol}$ photons $\left.\cdot \mathrm{m}^{-2} \cdot \mathrm{sec}^{-1}\right)$ and temperature $\left({ }^{\circ} \mathrm{C}\right)$ levels on the basis of (A) HPLC, (B) Spectrophotometric method

\section{DISCUSSION}

The results of chlorophyll and carotenoid concentration obtained by HPLC analysis were compared with the results from spectrophotometer. High values of correlation coefficients (0.970 for chlorophyll, 0.978 for carotenoid and 0.997 for car/chl) show a great concurrence of the results obtained by two independent methods. There were no observed degradation products of chlorophyll a in extracts from the cultures of G. amphibium, therefore the results from the spectrophotometric method were very similar to the results from HPLC. On the basis of the experiments it was found that, for the determination of pigment concentration in culture, the spectrophotometric method was very handy to use, especially if only the total sum of carotenoids was more important for us. The method 
permits us to achieve good results in very simply way, at inconsiderable financial outlays.

However, Murray et al. (1986) achieved low correlation, merely 0.54 , between the results of chlorophyll a concentration obtained by HPLC and spectrophotometer in allomers-and chlorophyllides-rich field samples. Similarly, Meyns et al. (1994) associated the differences in the measurements by chromatographic and spectrophotometric methods with the degradation products of chlorophyll a in samples. The results by spectrophotometer were about 10-15\% higher than by HPLC. Plante-Cuny et al. (1993) found that the presence of chlorophyllide a in deposit samples caused a rise in values of chlorophyll a concentration measured by spectrophotometer. The scientists suggested that the spectrophotometric method could be routinely used in pigments analysis provided that the amount of chlorophyllide a was not higher than $5 \%$ of the total sum of chlorophyll a and chlorophyllide a. Since there are degradation products in field samples the only reliable and recommended method to detect pigments is HPLC (Jeffrey et al., 1997). However, Louda and Monghkonsri (2004) achieved excellent results for the spectrophotometric chlorophyll a determination compared with HPLC derived data. The correlation coefficients were in the range 0.93610.9987. Unfortunately the correlation coefficient for the spectrophotometric determination of pheopigments (by the classic method of Lorenzen (1967) in comparison with HPLC results was poor (0.0271).

The analysis of the ratio of carotenoid pigments to chlorophyll a is useful to understand the reaction of organism to culture conditions. In many phytoplankton species growing at high irradiances it is often observed an increase in the ratio of carotenoids to chlorophyll a in their thylakoid membranes. Some carotenoid pigments, like $\beta$-carotene and zeaxanthine, can play important role in photoprotection (Richardson et al., 1983; Davison, 1991; Quesada et al., 1995; Roos and Vincent, 1998). The experiments showed an acclimation capacity of Baltic cyanobacterium $G$. amphibium to irradiance changes. The observed difference between the minimum values of the carotenoid ratio to chlorophyll a and the maximum ones in the range of tested factors was fourfold (Fig. 2). In another planktonic cyanobacterium, Pseudoanabaena galeata, it was found that in the range of irradiance from $0.5-100 \mu \mathrm{mol}$ photons $\cdot \mathrm{m}^{-2} \cdot \mathrm{sec}^{-1}$ the parameter changed merely $1.3 \times$ in the range of 1.67-2.14 (Romo, 1994). However, the ratio of carotenoids to chlorophyll a at Oscillatoria agardhii increased about $2.2 \times$ with an increase in irradiance from 50-230 $\mu \mathrm{mol}$ photons $\cdot \mathrm{m}^{-2} \cdot \mathrm{sec}^{-1}$ (Millie et al., 1990), but at Anabaena circinalis the values of the same relation were constant in the same range of irradiance (Millie et al., 1992). (Paerl et al., 1983) suggested that high ratio of carotenoids to chlorophyll a was correlated with an effective protection against photoinactivation of photosynthetic apparatus and also improved photosynthetic efficiency.

\section{CONCLUSION}

Spectrophotometric method can be successfully and universally applied for pigment analysis and in studies concerning photoacclimation strategies. This method enables estimation the amount of photosynthetic pigments in simple and quick way. Moreover, spectrophotometric method gives comparable results to HPLC method, especially in samples without degradation products of chlorophyll a.

\section{ACKNOWLEDGEMENT}

This study was supported by research grants from the Council for Science-Poland (6 PO4F 117 21, 3 PO4F 027 23).

\section{REFERENCES}

Anagnostidis, K. and J. Komarek, 1988. Modern approach to the classification system of cyanophytes. 3 - Oscillatoriales. Arch. Hydrobiol. Suppl. 80, Algological Studies, 50-53: 327-472.

Andersen, R.A., R.R. Bidigare, M.D. Keller and M. Latasa, 1996. A comparison of HPLC pigment signatures and electron microscopic observations for oligotrophic waters of the North Atlantic and Pacific Oceans. Deep Sea Res. Topical Stud. Oceanography, 43: 517-537. DOI: 10.1016/09670645(95)00095-X

Buchaca, T., M. Felip and J. Catalan, 2005. A comparison of HPLC pigment analyses and biovolume estimates of phytoplankton groups in an oligotrophic lake. J. Plankton Res., 27: 91-101. DOI: $10.1093 /$ plankt/fbh154pap

Davison, I.R., 1991. Environmental effects on algal photosynthesis: Temperature. J. Phycol., 27: 2-8. DOI: 10.1111/j.0022-3646.1991.00002.x

Fisher, R.A. and F. Yates, 1963. Statistical Tables for Biological, Agricultural and Medical Research. 6th Edn., Olivier and Boyd, Edinburgh, pp: 138.

Jeffrey, S.W., R.F.C. Mantoura and S.W. Wright, 1997. Phytoplankton pigments in oceanography: Guidelines to Modern Methods. 2nd Edn., UNESCO Publishing, Paris, France, ISBN 9231032755, pp: 661. 
Jodłowska, S. and A. Latała, 2003. Simultaneous separation of chlorophylls and carotenoids by RPHPLC in some algae and cyanobacteria from the southern baltic. Ocean. Hydrob. Stud., 32: 81-89.

Jodłowska, S. and A. Latała, 2010. Photoacclimation strategies in the toxic cyanobacterium Nodularia spumigena (Nostocales, Cyanobacteria). Phycologia, 49: 203-211. DOI: 10.2216/PH08-14.1

Latała, A. and S. Misiewicz, 2000. Effects of light, temperature and salinity on the growth and chlorophyll a content of Baltic cyanobacterium Phormidium amphibium. Arch. Hydrobiol. Supplementband, Algological Stud., 136: 157-180.

Latała, A., S. Jodłowska and F. Pniewski, 2006. Culture Collection of Baltic Algae (CCBA) and characteristic of some strains by factorial experiment approach. Algological Stud., 122: 137154. DOI: 10.1127/1864-1318/2006/0122-0137

Llewellyn, C.A., J.R. Fishwick and J.C. Blackford, 2005. Phytoplankton community assemblage in the English Channel: a comparison using chlorophyll a derived from HPLC-CHEMTAX and carbon derived from microscopy cell counts. J. Plankt. Res., 27: 103-119. DOI: 10.1093/plankt/fbh158

Lorenzen, C.J., 1967. Determination of chlorophyll and phaeopigments: Spectrophotometric equations. Limnol. Oceanogr., 12: 343-346.

Louda, J.W. and P. Monghkonsri, 2004. Comparison of spectrophotometric estimates of chlorophylls-a, -b, -c and 'pheopigments' in Florida Bay seston with that obtained by high performance liquid chromatography-photodiode array analyses. Fla. Scient., 67: 281-292.

Mantoura, R.F.C. and C.A. Llewellyn, 1983. The rapid determination of algal chlorophyll and carotenoid pigments and their breakdown products in natural waters by reverse-phase high-performance liquid chromatography. Anal. Chem. Acta, 151: 297-314. DOI: 10.1016/S0003-2670(00)80092-6

Meyns, S., R. Illi and B. Ribi, 1994. Comparison of chlorophyll-a analysis by HPLC and spectrophotometry: where do the differences come from? Arch. Hydrobiol., 132: 129-139.

Millie, D.F., C.M. Hersh and C.P. Dionigi, 1992. Simazine-induced inhibition in photoacclimated populations of Anabaena circinalis (Cyanophyta). J. Phycol., 28: 19-26. DOI: 10.1111/j.00223646.1992.00019.x

Millie, D.F., D.A. Ingram and C.P. Dionigi, 1990. Pigment and photosynthetic responses of Oscillatoria agardhii (Cyanophyta) to photon flux density and spectral quality. J. Phycol., 26: 660666. DOI: $10.1111 / \mathrm{j} .0022-3646.1990 .00660 . x$
Millie, D.F., H.W. Paerl and J.P. Hurley, 1993. Microalgal pigment assessments using highperformance liquid chromatography: A synopsis of organismal and ecological applications. Can. J. Fish Aquat. Sci., 50: 2513-2527. DOI: 10.1139/f93-275

Murray, A.P., C.F. Gibbs and A.R. Longmore, 1986. Determination of chlorophyll in marine waters: Intercomparison of a rapid HPLC method with full HPLC, spectrophotometric and fluorometric methods. Marine Chem., 19: 211-227. DOI: 10.1016/0304-4203(86)90024-1

Paerl, H.W., J. Tucker and P.T. Bland, 1983. Carotenoid enhancement and its role in maintaining blue-green algal (Microcystis aeruginosa) surface blooms. Limnol. Oceanogr., 28: 847-857.

Plante-Cuny, M.R., C.H. Barranguet, D. Bonin and C. Grenz, 1993. Does chlorophyllidea reduce reliability of chlorophylla measurements in marine coastal sediments? Aquatic Sci., 55: 19-30. DOI: 10.1007/BF00877256

Quesada, A., J.L. Mouget and W.F. Vincent, 1995. Growth of Antarctic cyanobacteria under ultraviolet radiation: UVA counteracts UVB inhibition. J. Phycol., 31: 242-248. DOI: 10.1111/j.0022-3646.1995.00242.x

Riaux-Gobin, C., C.A. Llewellyn and B. Klein, 1987. Microphytobenthos from two subtidal sediments from North Brittany. II. Variations of pigment compositions and concentrations determined by HPLC and conventional techniques. Mar. Ecol. Prog. Ser., 40: 275-283.

Richardson, K., J. Beardall and J.A. Raven, 1983. Adaptation of unicellular algae to irradiance: An analysis of strategies. New Phytol., 93: 157-191.

Ritchie, R.J., 2006. Consistent sets of spectrophotometric chlorophyll equations for acetone, methanol and ethanol solvents. Photosynth. Res., 89: 27-41. DOI: 10.1007/s11120006-9065-9

Romo, S., 1994. Growth parameters of Pseudanabaena galeata Böcher in culture under different light and temperature conditions. Arch. Hydrobiol., Algol. Stud., 75: 239-248.

Roos, J.C. and W.F. Vincent, 1998. Temperature dependence of UV radiation effects on Antarctic cyanobacteria. J. Phycol., 34: 118-125.

Schagerl, M. and G. Kunzl, 2007. Chlorophyll a extraction from freshwater algae-a reevaluation. Biologia, 62: 270-275. DOI: 10.2478/s11756-0070048-x 
OnLine J. Biol. Sci., 11 (2): 63-69, 2011

Stanier, R.Y., R. Kunisawa, M. Mandel and G. CohenBazire, 1971. Purification and properties of unicellular blue-green algae (order Chroococcales). Bacteriol. Rew., 171-205. PMID: 4998365

Stoń, J. and A. Kosakowska, 2002. Phytoplankton pigments designation-an application of RP-HPLC in qualitative and quantitative analysis. J. Applied Phycol., $\quad 14$ : 205-210. DOI: 10.1023/A:1019928411436

Strickland, I.D.H. and T.R. Parsons, 1972. A Practical Handbook of Seawater Analysis. 2nd Edn., Fisheries Research Board of Canada, Ottawa, pp: 310.
Wright, S.W., S.W. Jeffrey, R.F.C. Mantoura, C.A. Llewellyn and T. Bjornland et al., 1991. Improved HPLC method for the analysis of chlorophylls and carotenoids from marine phytoplankton. Mar. Ecol. Prog. Ser., 77: 183-196.

Wulff, A., S. Vilbaste and J. Truu, 2005. Depth distribution of photosynthetic pigments and diatoms in the sediments of a microtidal fjord. Hydrobiology, 534: 117-130. DOI: 10.1007/s10750-004-1417-x 